\title{
A földi telepítésü légvédelem új vezetési rendszere
}

\section{ELŐZMÉNYEK}

A honi légvédelmi rakéta fegyvernem aktív tűzeszközeinek felsőbb szintű irányítása az 1960-as és '70-es években „hagyományos vezetési modell” szerint történt. A légi céloknak a harci osztályok (a légvédelemben zászlóalj szintǔ szervezeti elemnek felelnek meg) közötti elosztása az ezred (dandár) harcállásponton rendelkezésre álló légihelyzet-információk alapján teljességgel egyszemélyi döntést igényelt (a segítők javaslatainak figyelembevételével). Az osztályok hangosbeszélő hírközlő eszközön szóbeli utasításokat kaptak, hogy mely célokat semmisítsék meg. A felderítést és azonosítást csak a légi helyzet általános képét ábrázoló tervtáblák (a valós helyzethez viszonyított 2-5 perc késéssel), a helyi felderítő-célmegjelölő lokátorok közvetlen adatai, illetve az elöljáróval létesített kapcsolat segítette.

A légi támadóeszközök adott térrészben egyidejűleg potenciálisan megjelenő mennyisége (tömeges légicsapás, komplex repülőcsoportok), és ezzel összefüggésben a tűzkiváltó szervezetek szükséges és lehetséges darabszámának növelése (5 osztály: ezred, több alárendelt már dandár) olyan kihívást jelentett a vezetés számára, amely az egyszemélyi felelősség megtartásával, de automatizálási-számítástechnikai háttér nélkül már nem volt megvalósítható.

A honi légvédelmi rakétaeszközök automatizált vezetési rendszerének első képviselője Magyarországon 1981-ben a VEKTOR-2VE (5N35E) ${ }^{1}$ (Magyar Néphadsereg 11. Honi Légvédelmi Rakétadandár), majd néhány évvel később, annak továbbfejlesztett változata a SZENYEZS ME $(5 S Z 99 M E)^{2}$ (104. Honi Légvédelmi Rakétaezred) volt. (1. ábra) A korszak szovjet-orosz technikai színvonalát képviselő vezetési komplexumok - az eszközökhöz kapcsolt

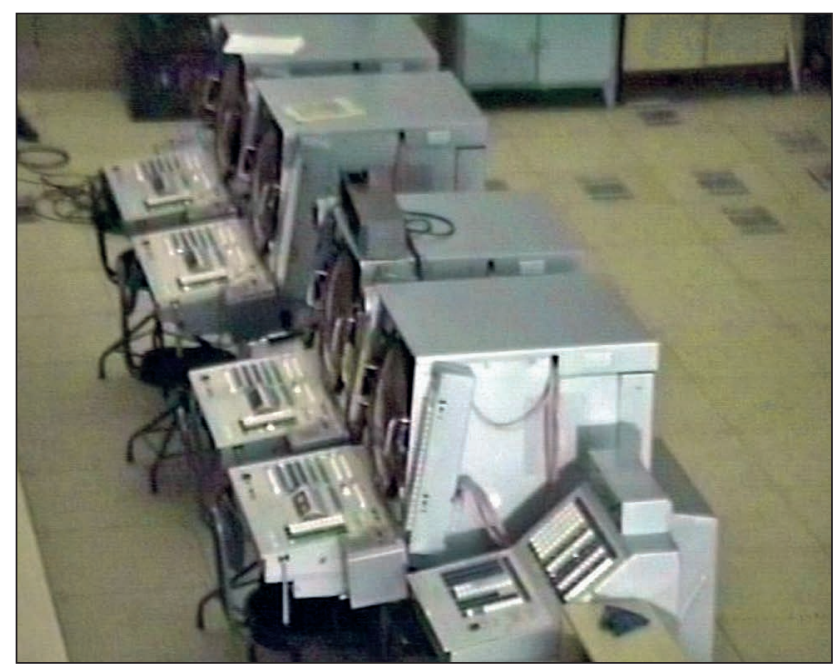

1. ábra. A SZENYEZS ME vezetési rendszer munkaállomásai az 1980-as évek végén [1]

rádiótechnikai szervezetek felderítési adatai alapján - képesek voltak 40 (VEKTOR-2VE), 50 (SZENYEZS ME) légi cél (célcsoport) egyidejű kezelésére, és 14-nél is több alárendelt osztály készültségi helyzetének követésére, harctevékenységének irányítására, továbbá 5-6 vadászrepülő műszeres rávezetésére az együtt települt vadászirányító pontról. A SZENYEZS ME a beszerzésre tervezett Sz-300 típusú komplexumok vezetésére is alkalmas volt.

Ezek a vezetési rendszerek a célpályáknak, a hozzárendelt rakétakomplexumok potenciális megsemmisítési zónáiba számított „beérkezési idő” alapján optimalizálták a célelosztást. A működés már digitális technikán alapult, de
ÖSSZEFOGLALÁS: A Zrínyi Honvédelmi és Haderőfejlesztési Program (Zrínyi HHP) keretében a földi telepítésű légvédelem eszközállománya is megújul. A légtérvédelmi képesség első új eleme a német Airbus Defence and Space vállalat által gyártott multifunkciós Föld-Levegő Rakéta Múveleti Központ, a SAMOC (Surface-to-Air Missile Operations Center). A SAMOC, vezetési eszközként megvalósítja a hozzárendelt földi telepítésű légvédelem összetevőinek stratégiai szintű koordinációját. A beszerzésre vonatkozó szerződést 2018. december 20-án írták alá a Honvédelmi Minisztériumban. Rendszerbe állítása - az új kis-közepes hatótávolságú légvédelmi rakétarendszer (NASAMS - National Advanced Surface to Air Missile System) - beszerzésének időpontjához igazodva, azt megelőzően valósul meg.

KULCSSZAVAK: Zrínyi HHP, földi telepítésű légvédelem, SAMOC, NASAMS
ABSTRACT: As part of the Zrínyi Defence and Military Development Program the elements of the ground based air defence will be replaced too. The first new element of the air defence capability is the multifunctional Surface to Air Missile Operations Center (SAMOC), developed and produced by Airbus Defence and Space (Germany). The SAMOC, as a management system handles the co-ordination of the subordinated ground based air defence assets at strategic level. The contract was signed at the Hungarian Ministry of Defence on 20th Decembre 2018. The system will reach its final operational capability prior to the introduction of the new small-medium range ground based air defence system (NASAMS - National Advanced Surface to Air Missile System).

\footnotetext{
* Nyugállományú vezérezredes. ORCID: 0000-0003-3289-2296

** Ezredes, az MHP Haderőtervezési Csoportfőnökség Fegyvernemi Képességtervező Főnökség főnöke. ORCID: 0000-0002-4489-331X

*** Nyugállományú alezredes. ORCID: 0000-0002-6333-2729
} 


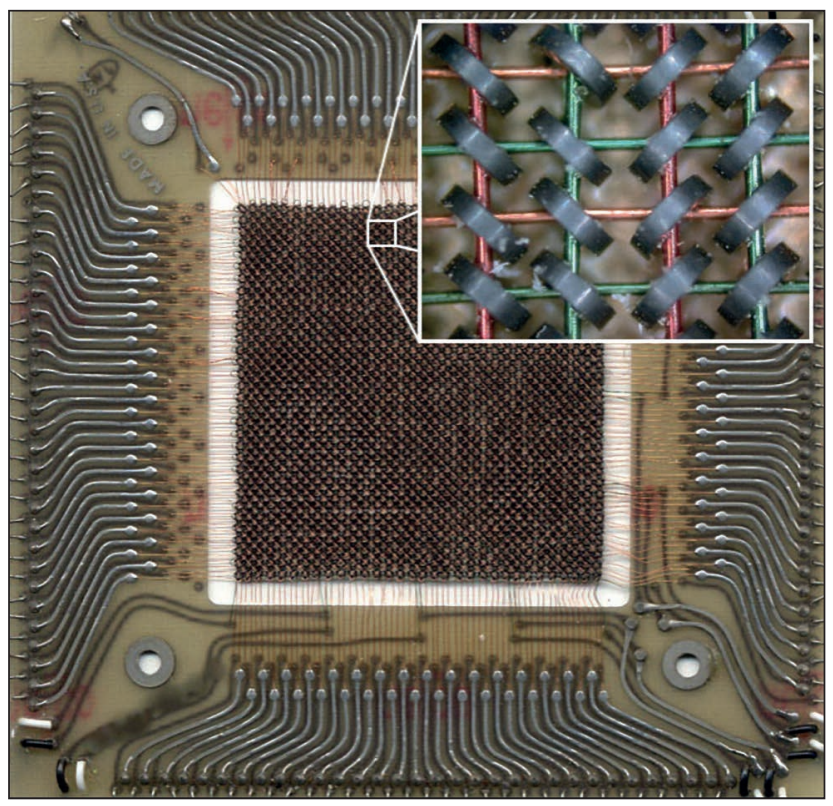

2. ábra. A ferritgyứrús írható-olvasható memóriaegység felépítése [2]

a kornak megfelelő számítási teljesítmény és az adattárolás lehetősége behatárolta a rendszer képességét. (2. ábra.)

A VEKTOR-2VE és a SZENYEZS ME vezetési komplexumokat - a haderőcsökkentés részeként a honi légvédelmi rakétaszervezetek teljes felszámolásával együtt - 2001ben kivonták a Magyar Honvédség hadrendjéből, majd azt követően az eszközöket fizikailag is megsemmisítették.

A VOZDUH-M ${ }^{3}$ néven ismert szovjet-orosz komplex vezetési és adattovábbító rendszer légvédelmi hadtest szintű eleme: a VSZ-11M44, 1987-től működött Veszprémben. (3. ábra.) Képes volt kezelni a rádiólokációs felderítőrendszereket (VP-01, VP-025, PORI ${ }^{6}$ ), a vadászrávezető állomásokat $\left(V P-11^{7}\right)$ és a VEKTOR-2VE és SZENYEZS ME eszközöket, de tűzvezetési lehetőségeit csak részben használták ki.

A szárazföldi katonai szervezetek közvetlen légvédelmi oltalmazását biztosító csapatlégvédelmi rakéta (KRUGKUB) egység-alegység vezetési rendszerei - a felderítőeszközök képességeihez igazodva - lehetővé tették az alárendelt ütegszervezetek (a légvédelemben a század alegység megfelelője) centralizált tűzvezetését, a P-40-es és P-18-as lokátorok oldalszög- és távolságadatait kiegészítő PRV-16-os magasságmérő koordinátái alapján. A NATO-

3. ábra. A VSZ-11M rendszer munkaállomásai a veszprémi védett vezetési objektumban, az 1980-as évek végén [3]

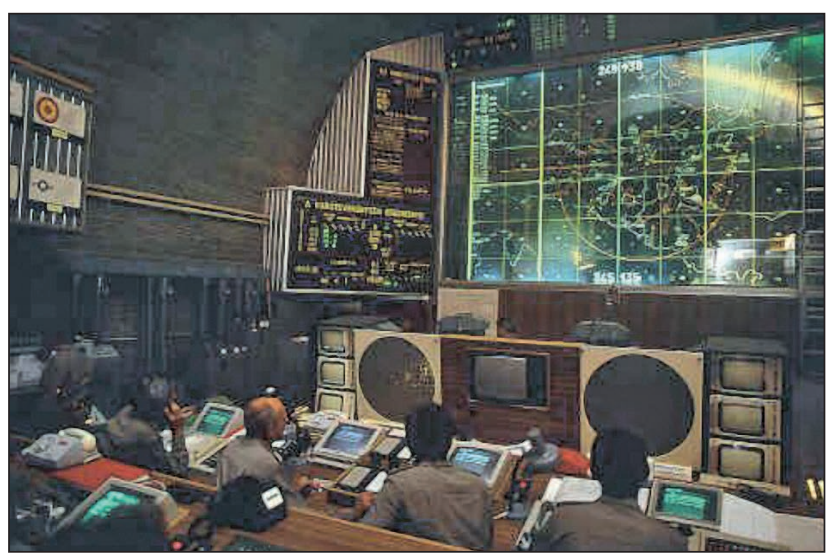

csatlakozást követően a rendszert hazai fejlesztéssel korszerűsítették, és kiegészült a Mistral közeli hatótávolságú légvédelmi rakéta szervezeti elemek centralizált vezetési képességével.

\section{A JELENKOR}

A nemzeti önrendelkezés alapfeltétele a légi felségjog érvényesítése, a légtér-szuverenitás megteremtése és állandó fenntartása. Magyarország ezt a képességet, a NATO szövetségi légtér részeként - az ellenőrzést végző felderítő és adattovábbító rendszerekhez történő közvetlen csatlakozással - jelenleg és a későbbiekben is önállóan kívánja megvalósítani. Napjainkban ez a tevékenység (az aktív tűzeszközöket tekintve) gyakorlatilag teljes egészében a harcászati repülőerők feladata.

A hadrendben lévő 2 K12 KUB típusú - rendeltetését tekintve - csapatlégvédelmi eszközök mennyisége, hatótávolsága, cél-tűzcsatorna száma és a rendelkezésre álló rakéták műszaki helyzete, továbbá azok azok korából adódó bizonytalan műszaki állapota miatt nem alkalmasak sem kiváltani, sem pedig érdemben kiegészíteni a repülőeszközöket. A '90-es évek második felében beszerzett francia Mistral légvédelmi rakétarendszer - ugyan fejlettebb müszaki színvonalat képvisel - ugyanakkor az eszköz csupán közeli hatótávolságú.

\section{A KöZELJöVő}

A Zrínyi HHP egyik kiemelt eleme a közepes hatótávolságú légvédelmi rakétavédelmi képesség helyreállítása. Ennek keretében kerülhetett sor többéves piackutatás, nemzetközi és hazai tárgyalás, részletes szakmai elemzésekegyeztetések és vezetői döntések után a multifunkciós Föld-Levegő Rakéta Műveleti Központ, a SAMOC (Surfaceto-Air Missile Operations Center) és a kis-közepes hatótávolságú NASAMS (National Advanced Surface-to-Air Missile System) légvédelmi rakétarendszer vételi szerződéseinek aláirására. Ugyan nem közvetlenül, de ehhez szervesen kapcsolódik a légtérellenőrzés új radareszközeinek (ELM-2084) $)^{8}$ beszerzése is.

A légvédelmi képesség helyreállításának első, új eleme a SAMOC lesz. Az eszközöket teljes körű műszaki ellenőrzés után szállítja a gyártó, azt követően a Magyar Honvédség komplex, helyi tesztelés után állítja rendszerbe. A hardverelőkészítéssel párhuzamosan megkezdődött a működtető szoftver - NATO-követelmények szerinti (5. ábra.), de nemzeti igényekkel kiegészített - módosítása, fejlesztése és véglegesítése. A kezdeti műveleti képesség - a COVID-19 világjárvány miatt - az eredetileg tervezetthez képest minimális csúszással, de még ebben az évben, a teljes műveleti képesség pedig 2022-ben valósul meg.

\section{A SAMOC}

A már üzemeltető és rendszerben tartó Németország és Szaúd-Arábia után Magyarország a harmadik felhasználó nemzet lesz.

A SAMOC olyan vezetési-irányítási komplexum, amely egységes, integrált módon valósítja meg a földi telepítésű légvédelem valamennyi hozzárendelt összetevőjének stratégiai szintű koordinációját nemzeti és multinacionális környezetben egyaránt. A harctevékenységek előzetes megtervezésével és a beágyazott kiképzési funkciókkal 


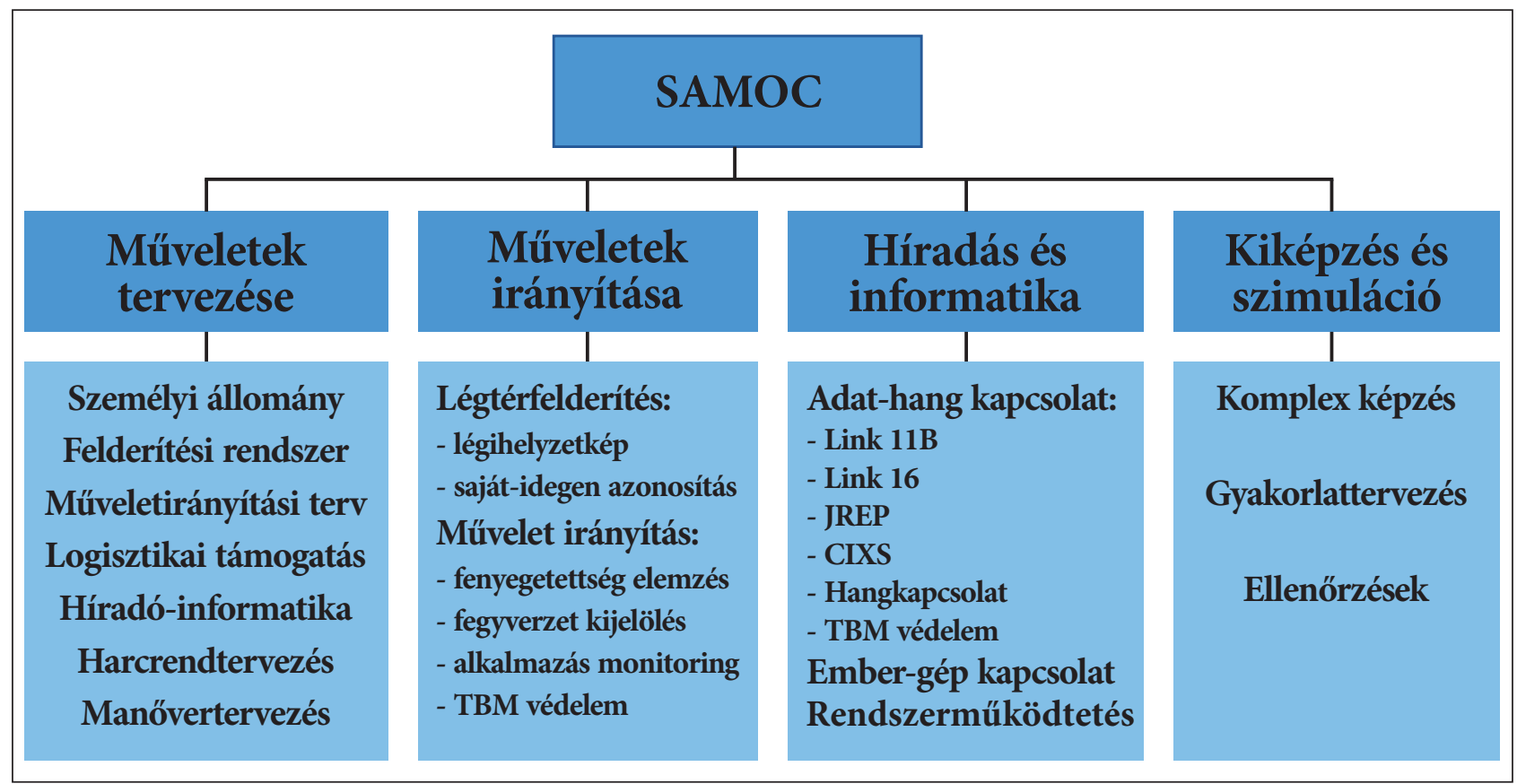

4. ábra. A SAMOC feladatrendszerének sémája (a szerzők szerkesztése a [4] alapján)

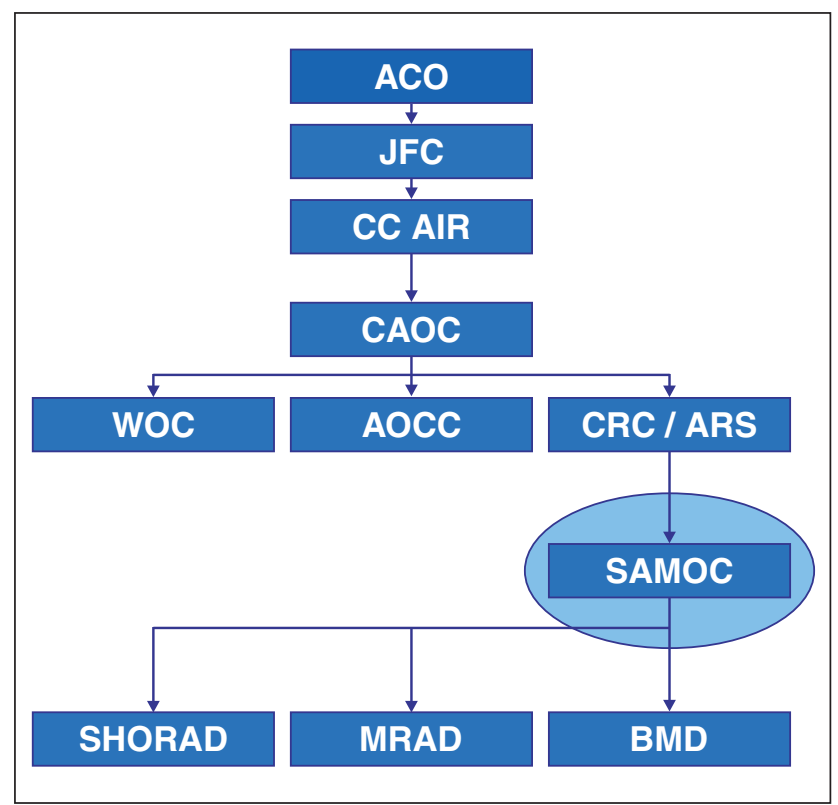

5. ábra. A SAMOC vezetési komplexum NATO müveleti rendszerben elfoglalt helye [4]

ACO: Szövetségi Müveleti Parancsnokság; JFC: Egyesített Erők Parancsnoksága; CC AIR: Légi Komponens Parancsnokság; CAOC: Légi Műveleti Központ; WOC: Egység Műveleti Központ; AOCC: Légi Műveletvezetési Központ; CRC: Irányítóközpont; ARS: Légiirányítási Központ/Valós idejü légi helyzetkép Előállító Központ/Szenzoradatgyűjtő és integráló Központ; SAMOC: FöldLevegő Rakéta Műveleti Központ; SHORAD: Kis hatótávolságú légvédelem; MRAD: Közepes hatótávolságú légvédelem; BMD: Ballisztikusrakéta-védelem

együtt, a teljes BMC4I (Battle Management Command, Control, Communications, Computers and Intelligence) feladatkör megoldására alkalmas. (4. ábra.) A rendszer, további - szükséges - adatok alapján képes ballisztikus rakétavédelmi számításokat végezni és a megsemmisítő tűzeszközöket irányítani.
Működtetése modern felhasználói felületeken történik, nagy méretű és nagy felbontású grafikus megjelenítéssel. A nyitott architektúra következtében a rendszer készen áll a további fejlesztésekre és jövőbeni újabb szabványú protokollok kezelésére. A SAMOC a jelenlegi legkorszerübb légvédelmi technológiát képviseli, kompatibilis és közvetlenül összekapcsolható a hasonlóan fejlett, jelenleg is állandóan működő NATO rendszerközpontokkal.

A rendszer gyors, megbízható, pontos információkat szolgáltat a valós idejü légi helyzetről. Felméri, elemzi a lehetséges fenyegetéseket és optimalizálja a rendelkezésre álló aktív védelmi fegyverek alkalmazását. Szabványos harcászati adatkapcsolatok útján valós idejü (realtime), illetve a katonai üzenetkezelési protokollok szerinti ütemezéssel késleltetett (non realtime) - hálózatközpontú működést valósít meg. (6. ábra.)

A SAMOC hardverkiépítése alapváltozat szerint két, önállóan is működőképes félkészleti rendszerből áll. Az elhelyezés történhet mobil (ISO-szabványnak megfelelő méretű) konténerekben, illetve állandó vezetési létesítményben, ez utóbbi esetében védett vagy akár egyszerű hivatali munkakörnyezetben is. (7. ábra.)

\section{6. ábra. Szabványos harcászati és üzenetkezelési} protokollok [5]

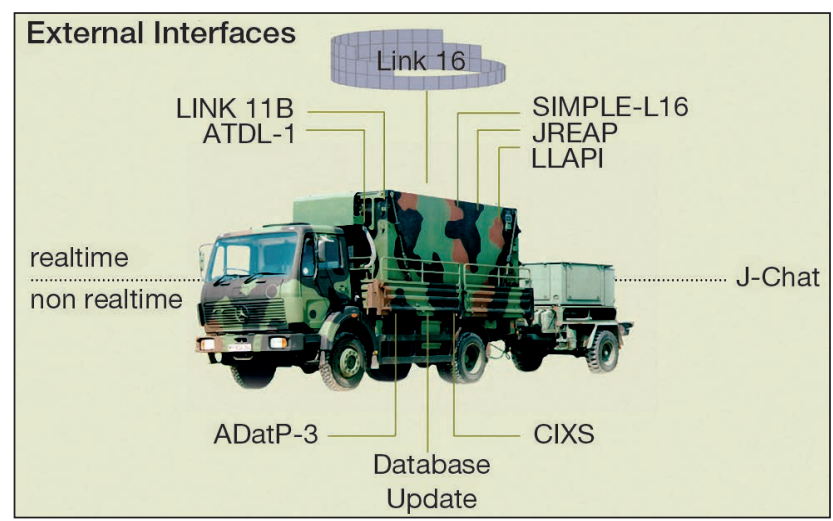



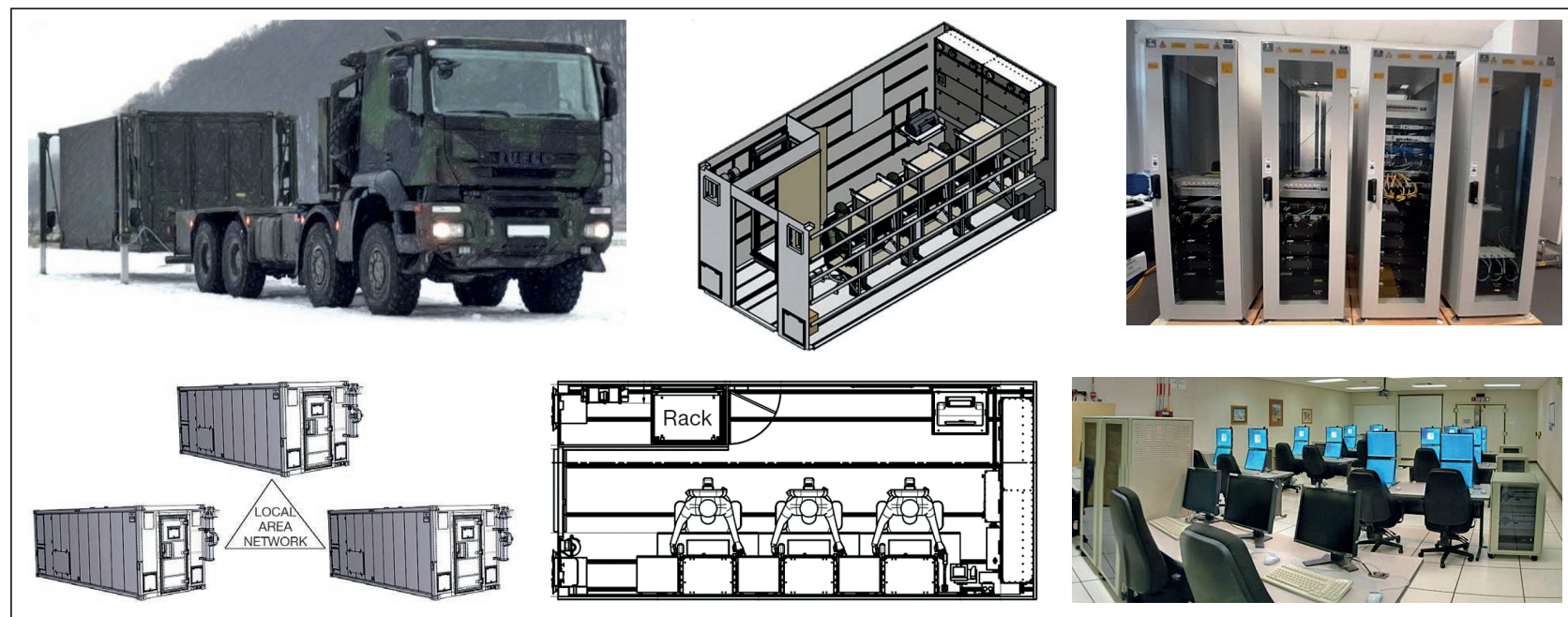

7. ábra. A SAMOC-rendszer mobil és stacioner elhelyezésének lehetséges változatai (a szerzők szerkesztése a [6] alapján)

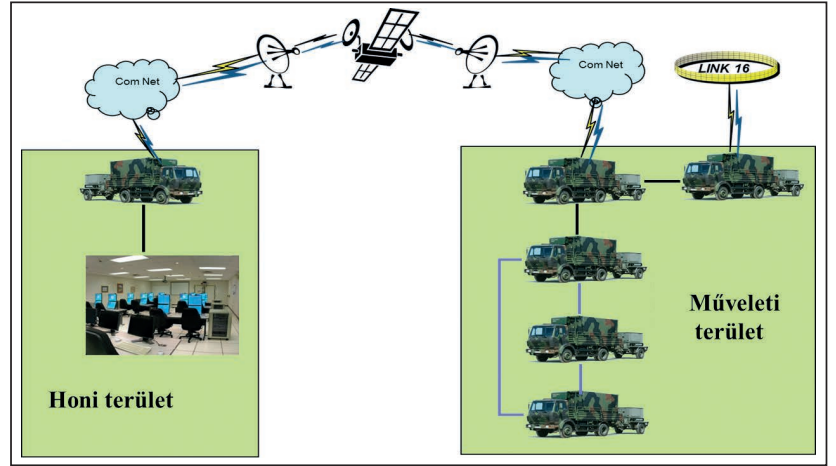

8. ábra. Stacioner és mobil telepítésű SAMOC félkészlet müholdas kapcsolati változata (a szerzők szerkesztése a [4] alapján)

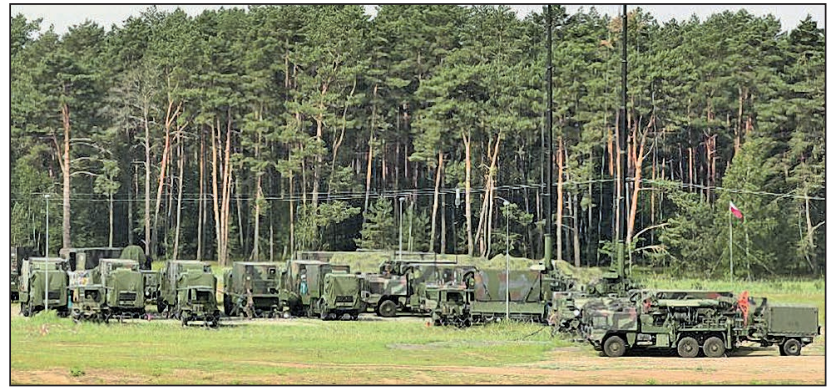

9. ábra. Mobil SAMOC a Tobruq Legacy 2019 NATO-gyakorlaton, Lengyelországban [6]
Egy félkészlet egyidejűleg vagy művelettervezést, vagy pedig közvetlen múveletirányítást végezhet. A munkaállomások maximális száma kötött, de a feladatkör felcserélhető, továbbá - megfelelő kommunikációs rendszeren keresztül - akár más földrajzi elhelyezésben is rugalmasan kezelhető. (8. ábra.) Ennek egyik konkrét példájaként említhető a 2013-ban, a törökországi „Active Fence” (Aktív Kerítés) kódnevű NATO-küldetés során német honi területen megvalósított tervezés, és a Kahramanmaras térségében (város Törökország déli részén) telepített Patriot ütegek irányítása.

A SAMOC számos harcászati gyakorlaton - JPOW (Joint Project Optical Windmill), JAWTEX (Joint Air Warfare Tactical Exercise), Tobruq Legacy (9. ábra.) -, NATO PfP (Partnership for Peace) keretben (Svédország, Kazahsztán) és a NATINAMDS ${ }^{9}$ programban történő részvétellel bizonyította a stratégiai vezetési képességet.

Az ipari-katonai követelményeknek megfelelő hardverkiépítés szoftveres hátterében a világ egyik vezető, nyílt forráskódú szoftvervállalata által forgalmazott Linux kernel alapú operációs rendszer áll, és az ehhez fejlesztett célalkalmazások biztosítják a kezelői feladatok megoldását. (10. ábra.)

A kezdeti és a teljes alkalmazási képesség érdekében a beszállító cég két önálló fázisra bontott, speciális szoftverkezelő és hardver-szoftver üzemeltetési képzést vállalt. A programban résztvevők a későbbiekben biztosítják a bevezetés és a rendszerbe állítás humán erőforrását, majd azt követően oktatói szerepkörben a további működtető és kiszolgáló személyzet „betanítását”.

A rendszerben tartást többszintü, integrált logisztikai támogatás biztosítja. Első szinten az alkalmazó állomány végzi

10. a) és b) ábra. Művelettervezési és irányítási felületrészletek (a szerzők szerkesztései) [4]

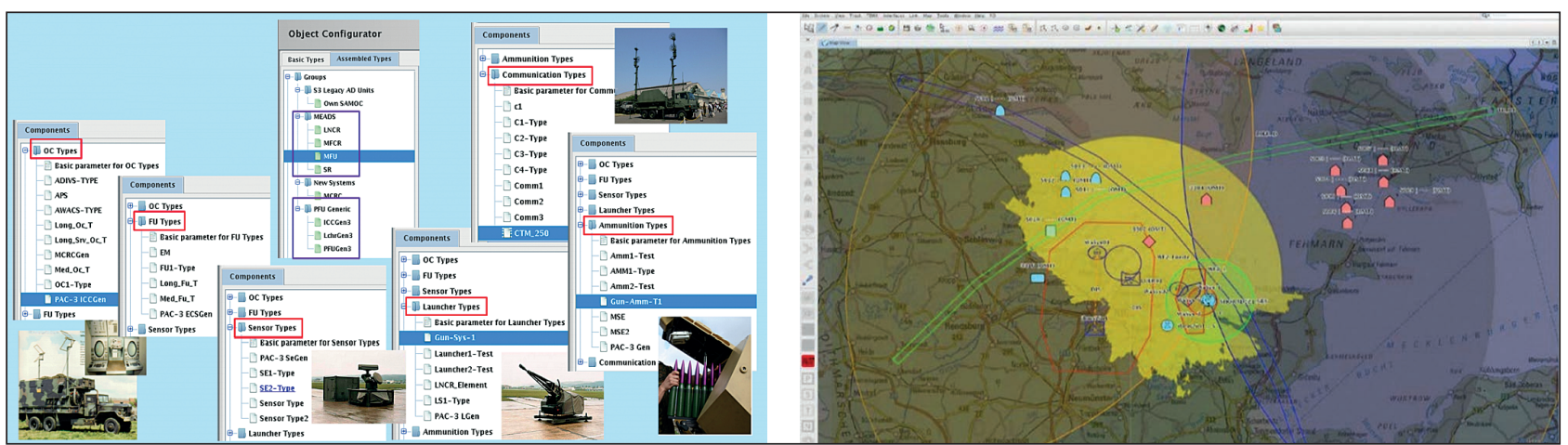



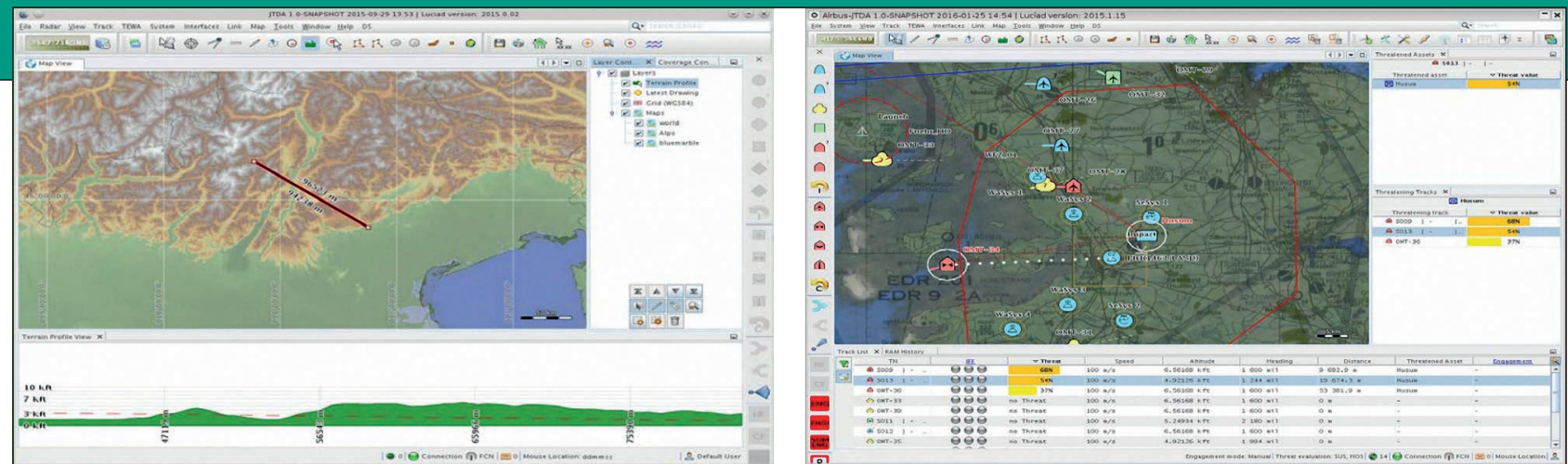

10. c) és $d$ ) ábra. Múvelettervezési és irányítási felületrészletek (a szerzők szerkesztései) [4]

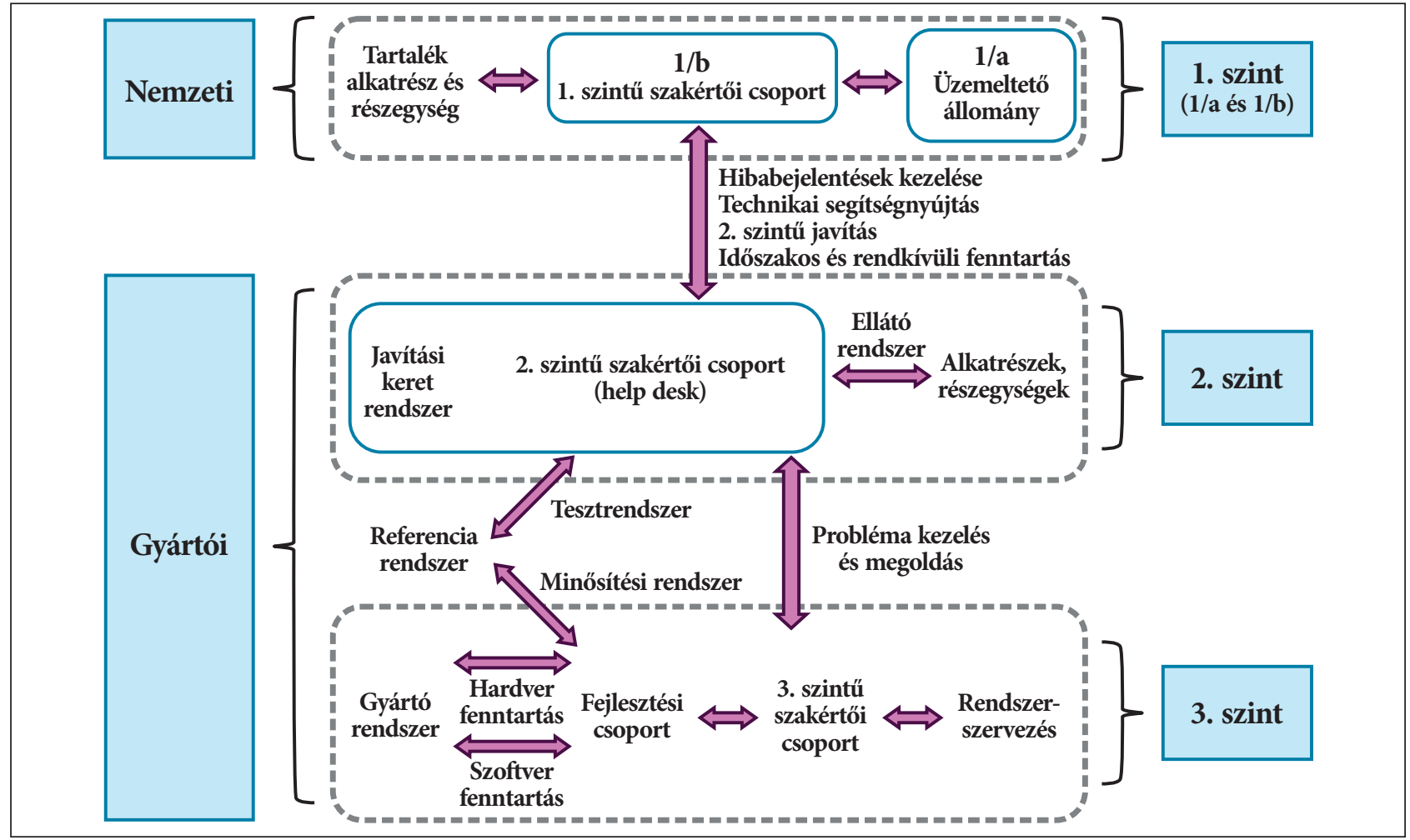

11. ábra. A SAMOC logisztikai támogatási rendszere (a szerzők szerkesztése) [4]

az általános üzemviteli feladatokat (beépített ellenőrzési funkciók futtatása, üzem- és egyéb anyagok feltöltése-pótlása stb.). Rendellenes vagy hibás működés esetén szakértői csoport végzi az alkatrészek, részegységek cseréjét a rendelkezésre álló tartalék, vagy külön igény alapján leszállított anyagokkal.

A logisztikai támogatás második szintjén a beszállító cég szakértői segítséget nyújtanak a hibajelenségek kezelésében és elhárításában, szükség esetén személyesen is közremúködnek a javításban, és biztosítják az igényelt anyagok, alkatrészek, részegységek szálítását.

A harmadik szinten közvetlenül a gyártó fejlesztő és szakértő csoportjai végzik a közbülső szint lehetőségeit is meghaladó hardver-szoftver problémák kezelését és megoldását, új rendszerelemek és szoftververziók előkészítését. A 2. és 3. szint feladatainak megoldását gyári referenciarendszer segíti. (11. ábra.)
Tekintettel arra, hogy a SAMOC rendszerbe állítása időben megelőzi a NASAMS légvédelmi rakétaeszközök beszállítását, a gyártó AIRBUS - az átmeneti időszakra - alkalmassá teszi a vezetési rendszert a jelenleg még hadrendben lévő KUB ütegszervezetek irányítására is.

\section{ÖSSZEGZÉs}

A SAMOC és a már ugyancsak aláírt beszerzési szerződés szerinti NASAMS légvédelmi rakétarendszer magas szintű automatizáltsága - a korábbi és jelenlegi hadrendi eszközökhöz viszonyítva - kisebb létszámú személyzetet igényel. Ugyanakkor a rendszerben tartás és a harci alkalmazás nélkülözhetetlen feltétele marad a képzett és erre felkészült, szakmai hivatástudattal rendelkező személyi állomány.

\section{HivATKOZOTT IRODALOM}

[1] https://simhq.com/forum/ubbthreads.php/ubb/printthread/Board/339/main/386010/type/thread Elérés ideje: 2021.03.10;

[2] https://upload.wikimedia.org/wikipedia/commons/d/df/Ferrite_core_memory.jpg Elérés ideje: 2021.03.10.;

[3] Teczely Béla, „Automatizált légi vezetés-irányítás, múlt, jelen, jövő (?)” Repüléstudomány 2004. Különszám. http://www.repulestudomany.hu/kulonszamok/2004_cikkek/teczely_bela.pdf; Elérés ideje: 2021.03.10.; 
[4] Airbus SAMOC and further Air C2 Solutions Presentation to MOD of Hungary (pdf);

[5] https://www.intelligence-airbusds.com/en/8912-fortion-samoc-state-of-the-art-technology-for-air-defence Elérés ideje: 2021.03.03.;

[6] https://esut.de/en/2019/09/fachbeitraege/streitkraefte-fachbeitraege/14800/das-samoc-im-multinationalen-einsatzvernetzte-operationsfuehrung-waehrend-der-uebung-tobruq-legacy-2019/ Elérés ideje: 2021.03.11.;

[7] Palik Mátyás Csaba: Automatizált légvédelmi vezetési rendszerek keleten és nyugaton, összehasonlító elemzés http://www.repulestudomany.hu/tdk/2014_Palik_Matyas_Csaba_SZD.pdf Elérés ideje: 2021.03.04.

\section{JEGYZETEK}

1 1980-tól működött az érdi 20-as, védett harcállásponton a VEKTOR-2VE (5N35E) automatizált vezetési rendszer. Alapvető rendeltetése információk automatizált összegyűjtése, feldolgozása, továbbítása és a légvédelmi rakétadandár tüzének vezetése, az elfogó vadászrepülők műszeres rávezetése az ellenséges légi célokra. Az automatizált harcállásponton egy időben 40 légi cél adatainak vétele, feldolgozása és a dandár alárendeltségébe tartozó 14 légvédelmi rakétaosztály (Volhov, Nyeva, Vega) harctevékenységének, valamint 6 elfogó vadászrepülőgép automatizált célra vezetése zajlott. [7;60. 0.]

2 1988-ban a szarvaspusztai 50-es védett harcállásponton telepítették a rendszert, amelynek képességei a VEKTOR rendszerhez képest, a számítógép szoftverének köszönhetően gyarapodtak. A harcálláspont berendezései lehetővé tették az információk automatizált forrástól történő vételét, feldolgozását maximum 50 egyes és csoportos légi objektumról. Az eszköz 17 légvédelmi rakétaosztály vezetését tette lehetővé (Sz-75, Sz-125, Sz-200, Sz-300), amelyek összesen 24 tüzcsatornával rendelkezhettek. [7; 61. o.]

3 Az 1950-es évek végén kifejlesztett VOZDUH-1P összetevőkből kialakított VOZDUH-1M rendszerhez tartozó komplexumok alapvető és széles körben elterjedt eszközök voltak a Varsói Szerződést aláiró szocialista országokban, bár haditechnika-történeti kutatások a közelmúltban feltárták, hogy hamar áttértek korszerübb komplexumok telepítésére. [7; 57. o.]

4 A honi légvédelmi rendszer harcászati szintjének legfelső, a hadosztály (hadtest), illetve a rádiótechnikai dandár közös, megerősített harcálláspontjára telepítették. A rendszert speciálisan a légvédelmi magasabbegységek számára fejlesztették ki. Innen hajtották végre az alárendeltségébe tartozó légvédelmi rakéta, vadászrepülö, rádiótechnikai, rádiófelderítö-zavaró magasabbegységek, egységek és alegységek harctevékenységének centralizált-automatizált vezetését. [7; 56. 0.]

5 A VP-01M komplexumokat kis magasságú célokat felderító rádiótechnikai századoknál telepítették. A közvetlenül csatolt radarok által szolgáltatott adatokat ábrázolta, majd az információkat automatizáltan továbbította a VP-02M-mel felszerelt rádiótechnikai századhoz vagy az elöljáró harcálláspontjára. Megoldotta a parancsok vételét, jelentések küldését, kijelzését, valamint a vett információk tárolását. [7; 55. 0.]

6 A PORI (5D91) rendszer zászlóalj szinten telepített rádiólokációs információkat feldolgozó központ volt, amely 5 rádiótechnikai század által szolgáltatott adatokat volt képes venni, feldolgozni, ábrázolni és továbbítani. A komplexum számítógépe képes volt $1200 \mathrm{~km}$ távolságig, $40 \mathrm{~km}$ magasságig és $4000 \mathrm{~km} / \mathrm{h}$ célsebességig koordináta átszámításra, mozgásparaméter számításra, célútvonal korrekcióra, illetve az alárendelt századok felé történő célelosztásra. [7; 60-61. o.]

7 VP-11 komplexum a közvetlenül csatolt rádiólokátoroktól vett elsődleges, vagy az ASZPD-1 alrendszeren érkező másodlagos adatok alapján megoldotta az elfogók müszeres rávezetését. Legtöbbször a rádiótechnikai századoknál telepítették, de lehetséges volt közvetlenül a vadászrepülő ezred harcálláspontján is elhelyezni. [7; 54. o.]

8 Az ELM-2084 izraeli gyártású, földi telepítésǔ, mobil, multifunkciós radar (MMR), amelyet az ELTA, az Israel Aerospace Industries leányvállalata gyárt. A radar felismeri és nyomon követi mind a repülőgépeket, mind a ballisztikus rakétákat és tűzvezetést biztosít a rakéták vagy a tüzérségi légvédelem számára. A radart megvásárolta és hadseregében üzemelteti: Izrael, Kanada, Szingapúr és a Cseh Köztársaság.

9 NATO Integrated Air and Missile Defence System - NATO Integrált Légvédelmi és Rakétavédelmi Rendszer.

\section{Elhunyt M. Szabó Miklós hadtörténész}

\section{2-2021}

Életének 78. évében, 2021. március 9-én elhunyt M. Szabó Miklós hadtörténész, az MTA rendes tagja, nyugállományú altábornagy, a Zrínyi Miklós Nemzetvédelmi Egyetem rector emeritusa, lapunk szerzője és lektora. Altábornagy Úr 1987-ben lett a hadtudomány doktora, 1988ban nevezték ki egyetemi tanárrá. A Magyar Tudományos Akadémiának 2001-től vált levelező, 2007-től pedig rendes tagjává. Kutatási területei közé tartoztak a második világháború hadműveletei, a Magyar Királyi Honvéd Légierő és a második világháború utáni magyar katonai felsőoktatás története. A Magyar Tudományos Müvek Tárában 250 írását rögzítették.

Pályája során számos hazai és külföldi elismerésben részesült, több tudományos és közéleti tisztségét is betöltött. Kollégái, hallgatói egyaránt tisztelték felkészültségét, alaposságát, tudományos alázatát és fanyar humorát. Élete utolsó percig oktatott és kutatott, még rengeteg megvalósítandó terve volt. 1984-től a Zalka Máté Katonai Müszaki Főiskola, majd 1991-től a Bólyai János Katonai Műszaki Főiskola parancsnoka volt.

A Zrínyi Miklós Nemzetvédel-

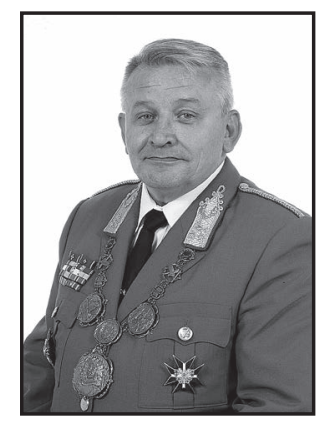
mi Egyetem létrehozásában megkérdőjelezhetetlen érdemeket szerzett. Sokat küzdött azért, hogy a katonai felsőoktatás tartalmában és nevében is egyetemi szintűvé váljon, kiváltság legyen ott végezni. 1996-tól 11 éven át volt az egyetem rektora. A Magyar Honvédség mai tisztikarának döntő többsége ott szerezte ismereteit, számukra M. Szabó Miklós mentor és személyes ismerős maradt.

A Haditechnika folyóirat többször fordult hozzá, mint megbízható és alapos lektorhoz. Munkájával soha nem késett, és véleményét mindig megalapozottan fogalmazta meg. Hiányozni fog...

Altábornagy Úr nyugodjon békében!

(Szerkesztőség) 